\title{
Means Testing of Public Pensions: The Case of Australia
}

\author{
George Kudrna
}




\title{
Means Testing of Public Pensions: The Case of Australia
}

\author{
George Kudrna \\ University of New South Wales \\ October 2015 \\ Michigan Retirement Research Center \\ University of Michigan \\ P.O. Box 1248 \\ Ann Arbor, MI 48104 \\ www.mrrc.isr.umich.edu \\ (734) 615-0422
}

\section{Acknowledgements}

The research reported herein was performed pursuant to a grant from the U.S. Social Security Administration (SSA) funded as part of the Retirement Research Consortium through the University of Michigan Retirement Research Center (5 RRC08098401-07). The opinions and conclusions expressed are solely those of the author(s) and do not represent the opinions or policy of SSA or any agency of the Federal Government. Neither the United States Government nor any agency thereof, nor any of their employees, makes any warranty, express or implied, or assumes any legal liability or responsibility for the accuracy, completeness, or usefulness of the contents of this report. Reference herein to any specific commercial product, process or service by trade name, trademark, manufacturer, or otherwise does not necessarily constitute or imply endorsement, recommendation or favoring by the United States Government or any agency thereof.

\section{Regents of the University of Michigan}

Michael J. Behm, Grand Blanc; Mark J. Bernstein, Ann Arbor; Laurence B. Deitch, Bloomfield Hills; Shauna Ryder Diggs, Grosse Pointe; Denise Ilitch, Bingham Farms; Andrea Fischer Newman, Ann Arbor; Andrew C. Richner, Grosse Pointe Park; Katherine E. White, Ann Arbor; Mark S. Schlissel, ex officio 


\title{
Means Testing of Public Pensions: The Case of Australia
}

\begin{abstract}
The Australian age pension is noncontributory, funded through general tax revenues and means tested against pensioners' private resources, including labor earnings. This paper constructs an overlapping generations (OLG) model of the Australian economy to examine the economy-wide implications of several counterfactual experiments in the means testing of the age pension. These experiments include policy changes that both relax and tighten the existing means test. We also consider a policy change that only exempts labor earnings from the means testing. Our simulation results indicate that tightening the existing means test, combined with lower income tax rates, leads to higher labor supply, domestic assets, and consumption per capita, as well as to welfare gains in the long run, while labor earnings exemptions from the means testing have largely positive effects on labor supply at older ages. Population aging is shown to further strengthen the case for the pension means testing.
\end{abstract}

\section{Citation}

Kudrna, George. 2015. “Means Testing of Public Pensions: The Case of Australia.” Ann Arbor, MI. University of Michigan Retirement Research Center (MRRC) Working Paper, WP 2016338. http://www.mrrc.isr.umich.edu/publications/papers/pdf/wp338.pdf

\section{Author acknowledgements}

This research was supported by the Australian Research Council Centre of Excellence in Population Ageing Research (CEPAR) under grant CE110001029 and by a Michigan Retirement Research Center (MRRC) grant. I gratefully acknowledge the comments by John Piggott on an earlier draft of this paper and would like to thank participants of the MRRC Researcher Workshop for comments and feedback. 


\section{Introduction}

The Australian age pension represents the first pillar of Australia's pension system and is currently the major income source for most Australian retirees. The pension is non-contributory, funded through general tax revenues and means tested against pensioners' private resources, including labour earnings. The means test has been an important component of the age pension since its introduction more than a century ago. Importantly, means testing (and the flat rate pension payments) largely accounts for low cost pension expenditure, which is about 2.9 percent of GDP now, rising to 4 percent in 2050 (Australian Treasury, 2010). This policy is much less expensive than in most OECD countries, where expenditures allocated to retirement payouts average 9.5 percent of GDP across the member countries (OECD, 2013).

The Australian government has recently implemented several changes to the means testing of the pension, with aims to better target the payments to those in need and to encourage labour supply of older Australians. These changes include an increase in the taper rate (at which the pension is withdrawn) from 0.4 to 0.5 and an exemption of up to $\$ 6,500$ of annual labour earnings from the means testing. ${ }^{1}$

In this paper, we assess the implications of several hypothetical policy changes to the means testing of the age pension. The main motivation is to examine further increases in the taper rate to contain rising pension expenditures and higher exemptions of labour earnings from the means testing - as extensions of the 2009 age pension reform. As many countries do not have targeted public pensions (e.g., New Zealand), we also assess policy changes that relax the existing

\footnotetext{
${ }^{1}$ The increase in the taper rate was part of the 2009 age pension reform that also included (i) a 10 percent increase in the maximum pension for single pensioners, (ii) gradual increases in the pension access age to 67 years and (iii) a new work bonus with only half of the first $\$ 13,000$ of annual labour earnings subjected to the means testing. In 2011, the work bonus was enhanced such that the labour earnings exemption from the means testing applied up to the first $\$ 6,500$ per year.
} 
pension means test by reducing the taper. Specifically, we consider the following two sets of policy experiments: (i) adjustments of the pension taper from the current rate of 0.5 to zero, 0.25 , 0.75 and one; and (ii) changes in labour earnings exemptions from the current exemption of up to $\$ 6,500$ per year to 100 percent and 0 percent.

The main objective of this study is to explore the implications of these means testing policy changes for incentives of individuals to work and save, for macroeconomic aggregates and individual welfare. While it is well known that public pensions may discourage life-cycle labour supply and saving (as they act as a substitute for private income in retirement), the effects of the means testing on labour supply and saving are not as clear-cut. On the one hand, means tests generate high effective marginal tax rates (EMTRs), which have negative implications for labour supply and the saving behaviour of older people. On the other hand, means tests reduce public pensions, thus resulting in higher life-cycle labour supply and saving. In addition, means tested pensions allow for lower taxes on workers, providing households with further work incentives. The paper also determines distributional welfare effects and draws out budgetary implications for the government. Understanding these effects will benefit not only to Australia but also to other ageing economies facing large public pension liabilities.

To undertake this analysis, we apply an extension of the overlapping generations (OLG) model developed for Australia by Kudrna and Woodland (2011a, b), with a more detailed disaggregation of households into income quintiles and an updated calibration to recent Australian data. Our methodology has a range of features that make it particularly appropriate for the analysis of the means testing of public pensions (not just in the Australian context, but worldwide). First, the model employs life-cycle utility maximisation with endogenous retirement and a broader pension means test imposed on both assets income and labour earnings—allowing 
for a different means test treatment of the two sources of private in- come. This is in contrast with most studies that assumed exogenous retirement and thus assessed only assets and/or assets income under the means test—see, for example, Sefton et al. (2008), Kumru and Piggott (2009, 2012), Cho and Sane (2013) and Kitao (2014). Second, we incorporate inter- and intragenerational heterogeneity among households into the model, which allows us to evaluate policy impacts upon different household types. Third, the model includes a detailed model-equivalent representation of Australia's age pension, superannuation and income tax policy settings and hence captures important interactions between household behaviour and these policy settings.

Another important contribution of our analysis to related literature, which has focused largely on the long term equilibrium effects (e.g., Maattanen and Poutvaara (2007) and Tran and Woodland, 2014), is that we investigate the implications of policy changes upon impact, over the transition and in the long term. The transitional effects of means testing pensions are also analysed by Kudrna and Woodland (2011a) and Fehr and Uhde (2013, 2014). In contrast to Kudrna and Woodland (2011a) who examined the hypothetical removal of the Australian pension means test, we concentrate on the policy changes that strengthen the means testing in order to contain government spending on the pension. Fehr and Uhde $(2013,2014)$ consider the means testing of only assets income, while one of the main objectives of our paper is to evaluate the effect of the means testing of income earned from employment on labour supply of older households.

The simulation results for strengthening the means test via a higher taper rate show significant reductions in age pension expenditures (by 17.04 percent for taper increased to one), allowing for lower income tax rates that are adjusted to maintain a balanced government budget. We show that further increases in the taper combined with lower income tax rates have positive effects on per capita labour supply (0.82 percent increase), domestic assets (4.28 percent increase) and 
consumption (1.63 percent increase). ${ }^{2}$ Interestingly, average labour supply at older ages also improves as most older households see their pensions reduced, with some elderly not qualifying for any pension and, therefore, no longer facing high EMTRs on their earnings. Similarly to Kumru and Piggott (2009) and Tran and Woodland (2014), we find positive effects of the increased taper on average welfare in the long term - driven by welfare gains attained by higher income types of households benefiting from reduced income tax rates. The long run welfare gains of the increased taper are shown to be larger in an endogenous interest rate environment and particularly in an ageing economy. However, the short term welfare effects are significantly negative for current pensioners experiencing large cuts in their pensions, as shown by Fehr and Uhde (2014).

The examined policy changes in labour earnings exemptions have much smaller aggregate effects due to relatively small numbers of people affected and assumed productivity rates of the elderly workforce. More importantly, we find that the labour earnings exemptions from the means testing have largely positive implications for average labour supply of older Australians. This result supports the findings of empirical literature that examined labour supply responses to changes in the earnings tests of social security benefits in other developed countries (see, for example, Baker and Benjamin (1999) for Canada, Disney and Smith (2002) for the UK and Friedberg (2000) for the US).

The rest of this article is organised as follows. The next section describes the overlapping generations model that we use for the policy simulations. Section 3 discusses the calibration of the model to the Australian economy and presents the benchmark solution for main life-cycle

\footnotetext{
${ }^{2}$ The percentage changes in the brackets show the long run implications of the taper rate increased to one, relative to the benchmark with the current taper rate of 0.5 .
} 
profiles and macroeconomic aggregates. Section 4 reports on the simulation results for the examined policy changes in the pension taper rate and labour earnings exemptions. Section 5 is devoted to a sensitivity analysis of several modifications of the model. Section 6 offers some conclusions and policy recommendations.

\section{Model description}

The model builds on the general equilibrium OLG model developed for Australia by Kudrna and Woodland (2011a, b), which is extended in this paper to include (i) a more detailed intragenerational heterogeneity based on income distribution data from Australian Bureau of Statistics (ABS) (2012a) and (ii) an updated calibration with a detailed representation of the age pension settings in 2012. It is a small open economy version of Auerbach and Kotlikoff's (1987) model that consists of household, production, government and foreign sectors.

The household sector is populated with 70 overlapping generations aged 21 to 90 years, with each generation consisting of five income types of households distinguished by their productivity and social welfare payments. Households face lifespan uncertainty described by survival probabilities and make optimal consumption/saving and leisure/labour supply choices to maximise their inter-temporal utility. Importantly, retirement from workforce is also endogenous and (similar to labour supply, consumption and savings) affected by the tax and retirement income policy settings. In terms of Australia's retirement income policy, the model incorporates essential features of the age pension and mandatory superannuation.

The production sector contains a large number of perfectly competitive firms. The firms demand capital and labour to produce a single all-purpose output good that can be consumed, invested in production capital or traded internationally. The government collects tax revenues from 
households and firms to pay for general government consumption and transfer payments to households. It is assumed that the government maintains a balanced budget by adjusting the progressive income tax schedule, as in Tran and Woodland (2014).

We employ a small open economy framework with an exogenous interest rate since that description best fits the Australian economy. Finally, equilibrium in the model requires labour, capital and goods markets to clear. That is, in every time period, (i) the demand for labour from perfectly competitive firms must equal the supply of labour from households; (ii) the value of the capital stock must equal domestic assets less foreign debt; and (iii) output is equal to the sum of private and public consumption, investment and trade balance.

\subsection{Demographics}

We consider a model economy that is populated by sequences of generations aged between 21 and 90 years $(a=21, \ldots, 90)$ at any time $t$. Each generation consists of five income types $i$ - the lowest, second, third, fourth and highest quintiles, with intragenerational shares given by $w_{i}$. Every year, a new generation aged 21 years enters the model structure and faces random survival with the maximum possible lifespan of 70 years, while the oldest generation aged 90 years dies. Lifespan uncertainty is described by the conditional survival probabilities, $s_{a}$. We assume stationary demographics with a constant population growth rate, $n$, which implies time-invariant cohort shares, $\mu_{a}=\left[s_{a} /(1+n)\right] \mu_{a-1}$. 


\subsection{Households}

Each $i$-type household that begins its economic life at time $t$ is assumed to optimally choose consumption, $c$, and leisure, $l$, at each age and the timing of retirement to maximise the expected lifetime utility function given by

$$
\max _{\left\{c_{t+a-21}^{i}, l_{t+a-21}^{i}\right.} \frac{1}{1-1 / \gamma} \sum_{a=21}^{90} S_{a} \beta^{a-21} u\left(c_{t+a-21,}^{i} l_{t+a-21}^{i}\right)^{1-1 / \gamma},
$$

subject to the per-period budget constraints written as

$$
\begin{array}{r}
A_{a, t}^{i}=(1+r) A_{a-1, t-1}^{i}+L E_{a, t}^{i}+A P_{a, t}^{i}+S A_{60, t}^{i}+S P_{a, t}^{i} \\
+S T_{a}^{i}+B_{a, t}^{i}-\lambda_{t} T\left(y_{a, t}^{i}\right)-\left(1+\tau^{c}\right) c_{a, t}^{i},
\end{array}
$$

where the annual utility, $u(c, l)=\left[c^{(1-1 / \rho)}+\alpha l^{(1-1 / \rho)}\right]^{1 /(1-1 / \rho)}$, being discounted by the subjective discount factor, $\left(\beta\right.$, and the unconditional survival probability, $S_{a}=\prod_{j=21}^{a} s_{j-1}$. The remaining parameters in (1) are the inter- and intra-temporal elasticities of substitution denoted by $\gamma$ and $\rho$ and the leisure preference parameter, $\alpha$.

In (2), $A_{a, t}^{i}$ denotes the stock of ordinary private assets held at the end of age $a$, and time $t$, which equals the assets at the beginning of the period, plus the sum of interest income, $r A_{a-1, t-1}^{i}$, labour earnings, $L E_{a, t}^{i}$, age pension, $A P_{a, t}^{i}$, superannuation payouts, $S A_{60, t}^{i}$ and $S P_{a, t}^{i}$, social transfer payments, $S T_{a}^{i}$, and accidental bequest receipts, $B_{a, t}^{i}$, minus the sum of income taxes, $\lambda_{t} T\left(y_{a, t}^{i}\right)$, and consumption expenditures, $\left(1+\tau^{c}\right) c_{a, t}^{i}$. Labour earnings are the product of labour supply, $1-l_{a, t}^{i}$, and the hourly wage, $w_{t} e_{a}^{i}$, where $w_{t}$ is the market wage rate and $e_{a}^{i}$ is the ageand income-specific earnings ability variable. The labour supply is required to be non-negative, 
$1-l_{a, t}^{i} \geq 0$. The income tax is a function of the taxable income, $y_{a, t}^{i}$, which comprises labour earnings, assets income and the age pension. ${ }^{3}$ Following Gokhale et al. (2001), we abstract from any intended bequests, with all intergenerational transfers being accidental. The accidental bequests, $B_{a, t}^{i}$, are assumed to be equally redistributed to all surviving $i$-type households between 45 and 65 years old. We also assume that households are born with no wealth and exhaust all wealth at age 90 (i.e., $A_{20, t}^{i}=A_{90, t+70}^{i}=0$ ) and that they are constrained from borrowing (i.e., $\left.A_{a, t}^{i} \geq 0\right)$

\subsection{Retirement income policy}

The Australian retirement income policy contains three pillars. The first is a mandatory, publicly-managed pillar represented by the age pension. The second is also mandatory, but is a privately-managed and fully-funded superannuation guarantee scheme. The third pillar includes other long term private savings such as voluntary superannuation. In the model, we consider the two publicly stipulated pillars_age pension and mandatory superannuation.

The age pension, $A P_{a, t}^{i}$, is paid to households of income type $i$ and age pension age ( $a \geq 65$ ) if they satisfy the following income test. ${ }^{4}$ Let $p$ denote the maximum age pension paid by the government to pensioners provided that their assessable income does not exceed the income threshold, $I T_{1}$. The maximum pension, $p$, is then reduced at the taper rate, $\theta$, for every dollar of assessable income above $I T_{1}$. Algebraically, the age pension benefit can be written as

\footnotetext{
${ }^{3}$ The parameter $\lambda_{t}$ is set to one in the benchmark model but it adjusts endogenously to maintain a balanced government budget after implementing each of the examined policy changes.

${ }^{4}$ In fact, the means test of Australia's age pension consists of both the income and assets tests, with the test that results in a lower pension payment being used. The model considers only the income test as it affects about 70 percent of those receiving part age pension. Note that the income test (also including assets income) binds for smaller amounts of assets, which in the model are never high enough for the assets test to be binding.
} 


$$
A P_{a, t}^{i}=\left\{\begin{array}{cr}
p & \text { if } \widehat{y}_{a, t}^{i} \leq I T_{1} \\
p-\theta\left(\widehat{y}_{a, t}^{i}-I T_{1}\right) & \text { if } I T_{1}<\widehat{y}_{a, t}^{i} \leq I T_{2} \\
0 & \text { if } \widehat{y}_{a, t}^{i}>I T_{2}
\end{array},\right.
$$

where $I T_{1}$ and $I T_{2}$ denote the lower and upper bound thresholds for the assessable income, $\hat{y}_{a, t}^{i}=r A_{a-1, t-1}^{i}+\max \left(\left(L E_{a, t}^{i}-\varpi\right), 0\right)$. Notice that $\hat{y}_{a, t}^{i}$ consists of interest earnings, $r A_{a-1, t-1}^{i}$, (from assets holdings) and labour earnings, $L E_{a, t}^{i}$, exceeding the exempted amount, $\varpi$. The superannuation guarantee mandates employers to contribute a given percentage of gross wages into the employee's superannuation fund. Accordingly, the model assumes that mandatory contributions are made by firms on behalf of working households at the contribution rate, $\mathrm{cr}$, from their gross labour earnings, $L E_{a, t}^{i}$. The contributions net of the contribution tax, $\tau^{s} \cdot c r$, are added to the stock of superannuation assets, $S A_{a, t}^{i}$, that earns fund income at the after-tax interest rate, $\left(1-\tau^{r}\right) r$. Superannuation assets are assumed to be preserved in the fund until households reach age 60. At that age, households are assumed to be paid out their superannuation assets as lump sums. The superannuation assets accumulation in the fund during $a \leq 60$ can be expressed as

$$
S A_{a, t}^{i}=\left[1+\left(1-\tau^{r}\right) r\right] S A_{a-1, t-1}^{i}+\left(1-\tau^{s}\right) c r \cdot L E_{a, t}^{i},
$$


where $\tau^{r}$ and $\tau^{s}$ denote the fund earnings tax rate and the contribution tax rate, respectively. We further assume that working households 60 years and older are paid mandatory contributions directly into their private assets accounts, denoted by $S P_{a, t}^{i}$ in (2). ${ }^{5}$

The policy changes to the means testing that we examine involve the changes in (i) the income taper denoted by $\theta$ in (3) and (ii) labour earnings exemptions. In case of labour earnings exemptions, we consider two policy changes. The first change is to extend the exemptions to 100 percent. Under that policy change, the assessable income in (3) is altered to include only interest earnings, $\hat{y}_{a, t}^{i}=r A_{a-1, t-1}^{i}$. The second policy change is to abolish the exemptions, with the assessable income altered to include both sources of private income in full, $\hat{y}_{a, t}^{i}=r A_{a-1, t-1}^{i}+L E_{a, t}^{i}$.

\subsection{Firms and technology}

The production sector assumes a large number of perfectly competitive firms that demand capital, $K_{t}$; labour, $L_{t}$; and investment, $I_{t}$; to maximise the present value of all future profits subject to the (per capita) capital accumulation equation:

$$
\begin{array}{cl}
\max _{\left\{K_{t}, L_{t}, I_{t}\right\}} & \sum_{t=0}^{\infty} D_{t}\left[\left(1-\tau^{f}\right)\left(F\left(K_{t}, L_{t}\right)-C\left(I_{t}, K_{t}\right)-I_{t}-(1+c r) w_{t} L_{t}\right)\right] \\
\text { s.t. } & (1+n) K_{t+1}=I_{t}+(1-\delta) K_{t},
\end{array}
$$

where $D_{t}=(1+n)^{t} /(1+r)^{t}$ accounts for discounting and population growth and $\tau^{f}$ stands for the effective corporation tax rate. The adjustment cost function is taken from Fehr (2000) and given by $C\left(I_{t}, K_{t}\right)=0.5 \psi\left(I_{t} / K_{t}-(n+\delta)\right)^{2} K_{t}$, where $\psi$ is the adjustment cost coefficient and $\delta$ denotes the capital depreciation rate. The CES production function is

\footnotetext{
${ }^{5}$ This is consistent with post-July 2007 policy, which allows such contributions by seniors to be immediately removed tax free from the fund.
} 
$F\left(K_{t}, L_{t}\right)=\kappa\left[\varepsilon K_{t}^{(1-1 / \sigma)}+(1-\varepsilon) L_{t}^{(1-1 / \sigma)}\right]^{[1 /(1-1 / \sigma)]}$, with the productivity constant, $\kappa$, the capital intensity parameter, $\varepsilon$, and the elasticity of substitution in production, $\sigma$.

Solving the firm's maximisation problem yields the first-order necessary conditions and gives expressions for the equilibrium wage rate, $w_{t}$; interest rate, $r$; and capital price, $q_{t}$.

\subsection{Government}

The government is assumed to maintain a balanced budget, which can be expressed, in per capita terms, as

$$
T R_{t}^{Y}+T R_{t}^{C}+T R_{t}^{S}+T R_{t}^{F}=G+S T+A P_{t}
$$

where the per capita expenditures are government consumption, $G$, and social transfer payments, $S T$, which both are assumed to be constant, and the expenditure on the age pension, $A P_{t}$, while $T R_{t}^{Y}, T R_{t}^{C}, T R_{t}^{S}$ and $T R_{t}^{F}$ are per capita tax receipts from the taxation of household income, consumption, superannuation and corporate profits, respectively. The proportional changes in the income tax schedule that are assumed to adjust endogenously to balance (6) are given by ${ }^{6}$

$$
\lambda_{t}=\frac{G+S T+A P_{t}-\left(T R_{t}^{C}+T R_{t}^{S}+T R_{t}^{F}\right)}{\sum_{i=1}^{5} \omega_{i} \sum_{a=21}^{90} \mu_{a} T\left(y_{a, t}^{i}\right)}
$$

\footnotetext{
${ }^{6}$ In Section 5, we consider an alternative budget-equilibrating tax instrument by adjusting the consumption tax rate.
} 


\subsection{Market structure and equilibrium}

The model is a small open economy model with the exogenous interest rate, $r .^{7}$ The accumulation of net foreign debt, $F D_{t}$, in per capita terms, is

$$
(1+n) F D_{t+1}-F D_{t}=T B_{t}-r F D_{t},
$$

where $T B_{t}$ is the trade balance and $r F D_{t}$ is the interest payments on net foreign debt.

The endogenous variables in the model are determined such that all agents (i.e., households, firms and the government) make their choices optimally and that all markets clear in every period. The equilibrium conditions for labour, capital and output markets are given by

$$
\begin{aligned}
L_{t} & =\sum_{i=1}^{5} \omega_{i} \sum_{a=21}^{90} e_{a, t}^{i}\left(h-l_{a, t}^{i}\right) \mu_{a}, \\
q_{t} K_{t} & =\sum_{i=1}^{5} \omega_{i} \sum_{a=21}^{90}\left(A_{a, t}^{i}+S A_{a, t}^{i}\right) \mu_{a}-F D_{t}, \\
Y_{t} & =\sum_{i=1}^{5} \omega_{i} \sum_{a=21}^{90} c_{a, t}^{i} \mu_{a}+I_{t}+G_{t}+T B_{t} .
\end{aligned}
$$

\section{Calibration and benchmark economy}

The benchmark economy is assumed to be in a steady state equilibrium. We calibrate this benchmark to key Australian aggregates averaged over the five-year period ending in 2012, with the tax and pension policy settings and parameters of that year. This section reports on the model parameterisation and then presents a comparison of the benchmark solution with Australian data for some variables.

\subsection{Parameterisation}

The values of the main parameters used in the benchmark model and the sources are pro- vided in Table 1. As shown, some of the parameters are taken from related literature, some exactly

\footnotetext{
${ }^{7}$ The exogenous interest rate assumption is relaxed in Section 5.
} 
match actual data and others are calibrated such that the benchmark solution yields outcomes consistent with observed data.

TABLE 1: Values of Main Parameters of Benchmark Model

\begin{tabular}{|c|c|c|c|c|}
\hline & & & Value & Source \\
\hline \multirow{22}{*}{ Description } & \multirow{3}{*}{ Demographics } & Population growth rate & 0.018 & $\begin{array}{l}\text { Calibrated Data } \\
\text { [a] }\end{array}$ \\
\hline & & $\begin{array}{l}\text { Fraction of households of income } \\
\text { type }\end{array}$ & All 0.2 & $\begin{array}{l}\text { Calibrated Data } \\
{[\mathrm{a}]}\end{array}$ \\
\hline & & Conditional Survival probabilities & ABS (2013a) & Data \\
\hline & \multirow{4}{*}{ Utility function } & $\begin{array}{l}\text { Inter-temporal elasticity of } \\
\text { substitution }\end{array}$ & 0.35 & Literature [b] \\
\hline & & $\begin{array}{l}\text { Intra-temporal elasticity of } \\
\text { substitution }\end{array}$ & 0.9 & Literature [b] \\
\hline & & Subjective discount factor & 0.985 & Calibrated \\
\hline & & Leisure preference parameter & 1.32 & Literature [b] \\
\hline & \multirow{5}{*}{ Technology } & Production constant & 0.885 & Calibrated \\
\hline & & $\begin{array}{l}\text { Elasticity of substitution in } \\
\text { production }\end{array}$ & 0.929 & Calibrated \\
\hline & & Capital share & 0.45 & Data \\
\hline & & Depreciation rate & 0.07 & Calibrated \\
\hline & & Adjustment cost parameter & 10 & Literature [c] \\
\hline & \multirow{10}{*}{ Policy Parameters } & $\begin{array}{l}\text { Maximum age pension p.a. (in } \\
\$ 100,000)\end{array}$ & 0.17469 & Data \\
\hline & & $\begin{array}{l}\text { Income free threshold p.a. (in } \\
\$ 100,000)\end{array}$ & 0.03976 & Data \\
\hline & & $\begin{array}{l}\text { Maximum earnings exemption p.a. } \\
\text { (in } \$ 100,000)\end{array}$ & 0.065 & Data \\
\hline & & Pension taper rate & 0.5 & Data \\
\hline & & $\begin{array}{l}\text { Mandatory superannuation } \\
\text { contribution rate }\end{array}$ & 0.09 & Data \\
\hline & & $\begin{array}{l}\text { Superannuation contribution tax } \\
\text { rate }\end{array}$ & 0.15 & Data \\
\hline & & $\begin{array}{l}\text { Effective superannuation earnings } \\
\text { tax rate }\end{array}$ & 0.075 & Data \\
\hline & & $\begin{array}{l}\text { Statutory consumption tax rate } \\
\text { [GST] }\end{array}$ & 0.1 & Data \\
\hline & & Statutory corporation tax rate & 0.3 & Data \\
\hline & & Income tax function & - & Estimated [d] \\
\hline
\end{tabular}

Notes: [a] Households are disaggregated into income quintiles based on ABS (2012a); [b] The values of these parameters are similar to Auerbach and Kotlikoff (1987) and Fehr (2000); [c] This value is taken from Auerbach and Kotlikoff (1987); [d] The function is estimated, using the 2011-12 income tax schedule. 


\subsubsection{Model parameters}

We assume a stationary demographic environment with the age specific survival rates, $s_{a}$, taken from the 2010-12 life tables (ABS, 2013a) and the annual population growth rate of $n=0.018$ is chosen to generate a realistic old-age dependency ratio of 0.22 . The intra- generational shares, $\omega_{i}$, are equal to 0.2 for each income type, which is based on the quintiles used by ABS (2012a).

The values assigned to the utility and technology parameters are standard in related literature. The calibrated utility parameters include the subjective discount factor, $\beta$, and the leisure preference parameter, $\alpha$, that target the capital to output ratio $(=3)$ and the average fraction of time spent working by those aged 25 to 60 years $(=0.33)$, respectively. Most of the production function parameters are also calibrated to replicate other calibration targets, including the investment rate of 0.09 and the foreign debt to capital ratio of 19.5 percent. The wage rate, $w$, is normalised to one and the exogenous interest rate, $r$, is set to 5 percent.

The values of the age pension and superannuation parameters are those applicable in 2012. The consumption and corporation tax rates are set to their statutory rates of 10 percent and 30 percent, respectively. We assume no government debt and use an income tax function that approximates the 2011-12 progressive income tax schedule. We also make use of adjustment parameters to target the ratios of consumption and corporate tax revenues to GDP and the ratios of public consumption, pension expenditures and other social welfare to GDP.

\subsubsection{Intragenerational heterogeneity}

The five income types of households (i.e., income quintiles) differ by their exogenously given earnings ability, $e_{a}^{i}$, and social transfer payments, $S T_{a}^{i}$ (excluding the age pension). The earnings ability (or the potential wage earned with all time endowment allocated to work) is 
constructed using the estimated lifetime wage function taken from Reilly et al. (2005) and income distribution shift parameters based on ABS (2012a) data. The social transfer payments are assumed to be received by households in the lowest to fourth quintiles aged younger than 65 years $(a<65)$ and are also derived from ABS (2012a), which provides the share of social welfare in gross total income for each income quintile. These government benefits (representing welfare payments such as family benefits and disability support pensions) allow us to match not only private income but also gross total income for each quintile.

\subsection{Benchmark solution and performance}

The benchmark solution is obtained by numerically solving the model for the initial steady state equilibrium, with the parameters and the policy settings specified above. We use the GAMS software and the Gauss-Seidel iterative method to solve for the initial steady state equilibrium as well as transition paths for the examined policy changes. The algorithm involves choosing initial guesses for some variables and then updating them by iterating between the production, household and government sectors until convergence (see Kudrna and Woodland (2011a) for exact computational steps).

\subsubsection{Life-cycle profiles}

The benchmark solution for life-cycle profiles of consumption, labour supply, total assets, labour earnings, total income and age pension payments is depicted by Figure 1. The life-cycle profiles of consumption expenditures, labour supply and labour earnings for each income quintile exhibit the standard hump-shape, rising at early ages and then declining. The shapes of these profiles reflect the assumed hump-shaped productivity profile and the increasing mortality risk, while the age profile of total assets reflects the saving decision along with the assumed zero initial and terminal asset holdings by households. 


\section{FIGURE 1: Benchmark Steady State Solution for Life-cycle Household Variables}
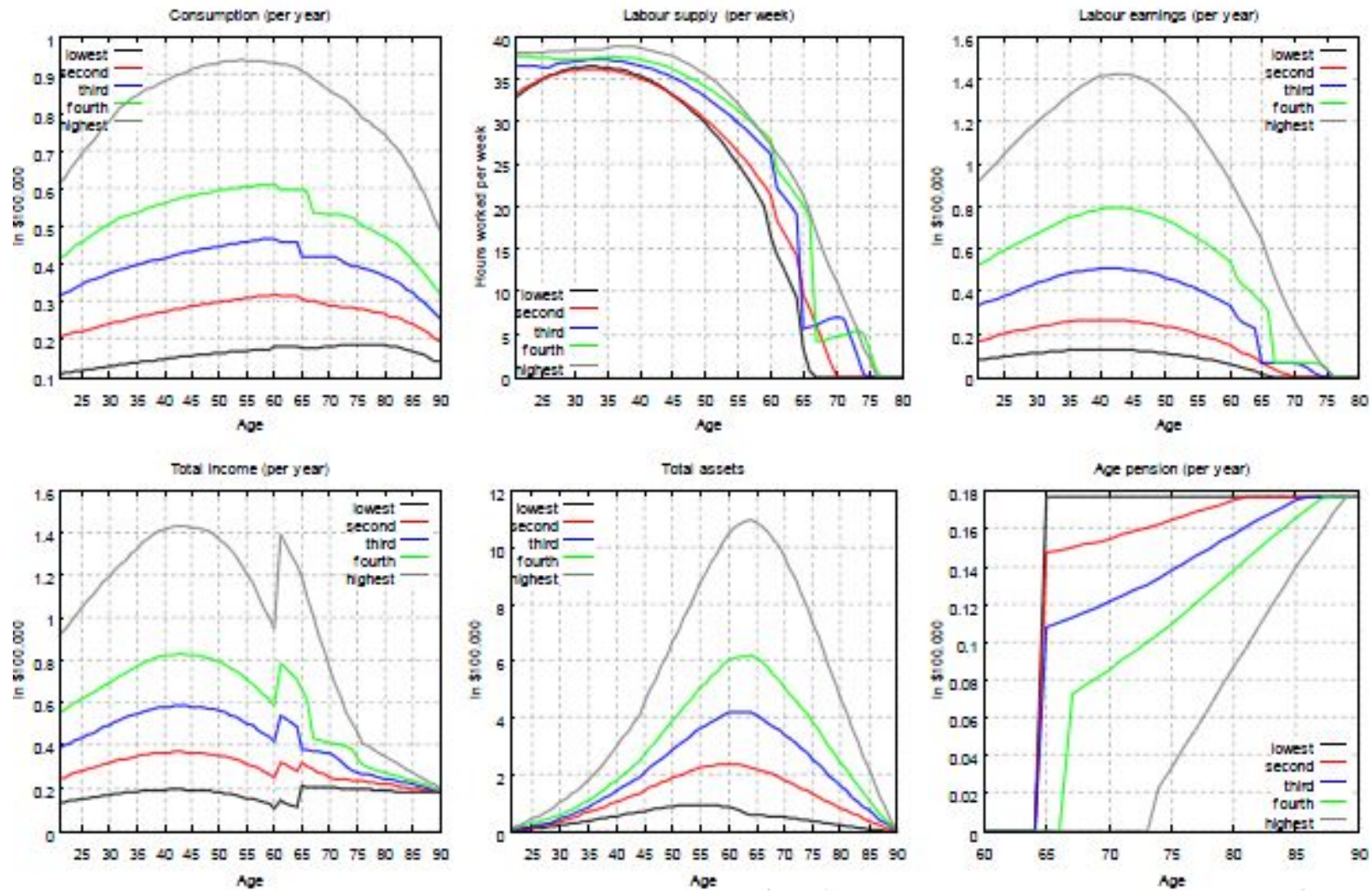

Notes: Total assets include superannuation assets and ordinary private (liquid) assets. Total income consists of taxable income (labour earnings, private asset income and the age pension) and other social transfers, which are income-specific.

Figure 1 also shows sudden reductions in consumption, labour supply and labour earnings for some income quintiles at older ages, which are due to the retirement income policy. First, the superannuation savings are illiquid until age 60, at which each quintile is assumed to receive a lump sum payout. Subsequently, the payout has an income effect on labour supply, with the drop in labour supply being particularly large for lower income types. ${ }^{8}$

\footnotetext{
${ }^{8}$ As the legislation prohibits from borrowing against superannuation assets, we impose the non-negative assets constraint to prevent younger households from such borrowing. This constraint binds for lower income types prior to reaching age 60 and so the availability of their superannuation increases their consumption and leisure (implying lower labour supply).
} 
Second, households at age 65 become eligible for the age pension that is means tested. The graph with the age profiles of pension payments shows that the lowest quintile gets full age pension from age 65 onwards. The second and third quintiles receive part age pension at age 65 , while households in the highest quintile do not receive any pension until age 72 . The two lowest quintiles reduce their working hours at age 65 as a result of the income effect of the pension payment. The sudden drop in labour supply of the third quintile is due predominantly to the effective means testing with the preferential treatment of labour earnings. In particular, households in the third quintile at early age pension ages reduce their working hours to earn exactly $\$ 6,500$ per year that is not means tested. The same labour supply behaviour is shown for the fourth quintile at age $67 .{ }^{9}$ The behavioural effects of the age pension on the highest income quintile are insignificant because the pension is of less importance to them in comparison with lower quintiles.

\subsubsection{Data comparison}

We now compare some of the life-cycle profiles and the main macroeconomic solutions generated by the benchmark steady state model with Australian data. The model-generated profiles for labour supply, labour earnings and pension payments averaged across the quintiles and the cross-section data derived from HILDA surveys (Wooden et al., 2002) are plotted in Figure 2. The comparison reveals similar shapes as well as levels of the model-generated and data-based profiles for the three selected household variables.

\footnotetext{
${ }^{9}$ Older households in the fourth quintile work less than households of the same ages in the third quintile because they are assumed to earn a higher effective wage.
} 


\section{FIGURE 2: Comparison of Selected Average Life-cycle Profiles with Actual Data}
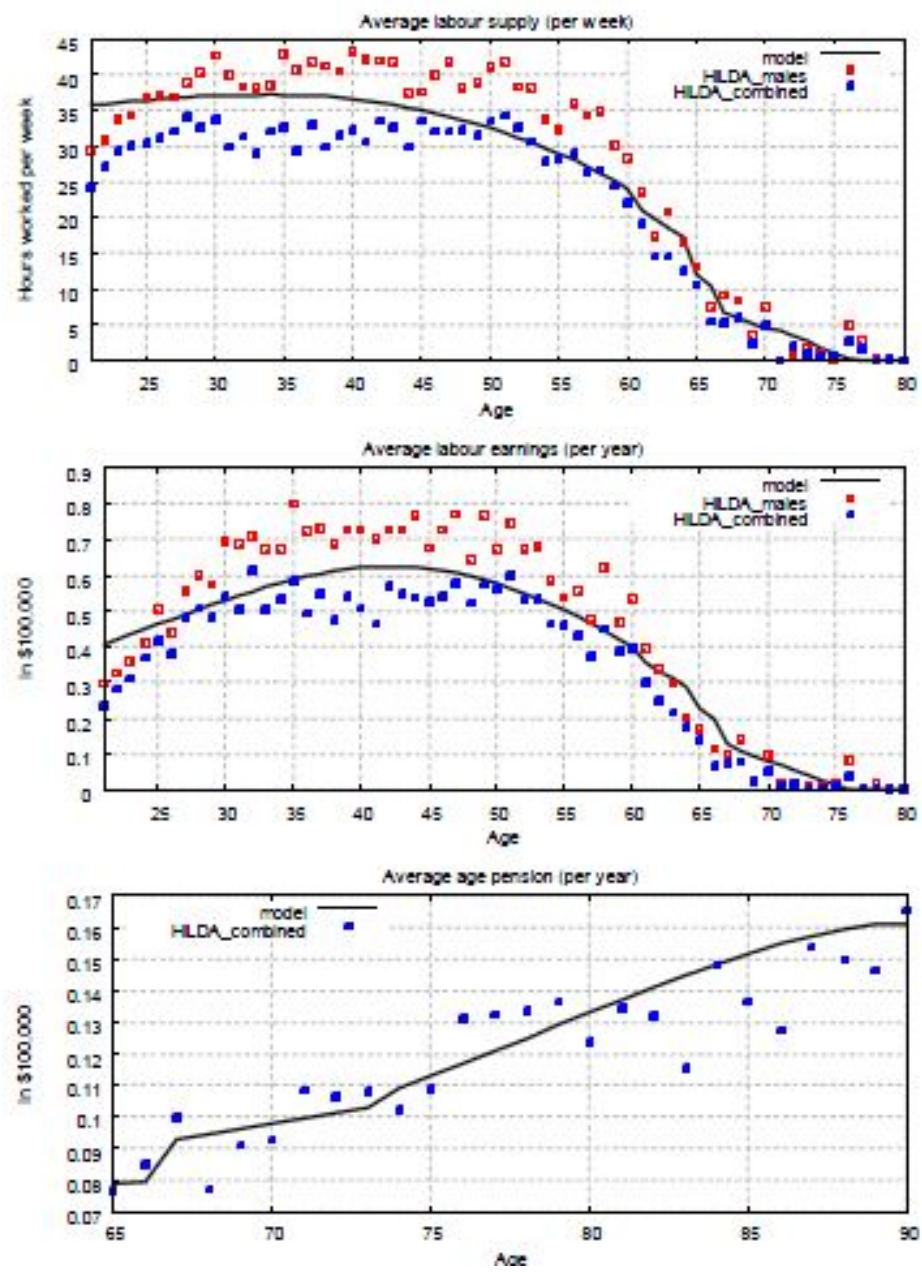

Notes: The HILDA profiles are derived from the individual data set of wave 10 conducted in 2010. The combined profiles show the average across males and females. The HILDA values for labour income and age pension are inflated at the wage inflation rate of $3.5 \%$ to 2012.

Table 2 compares main aggregate solutions with actual values averaged over five years ending in June 2012 and taken from ABS (2012b, 2013b, 2013c). As shown, the benchmark solution for the components of aggregate demand presented in percent of GDP (or output) are very close to their actual values, except for the trade balance, which is positive and implied by the targeted foreign debt to capital ratio. Similar conclusions can be drawn for government indicators, some 
of which are used as the calibration targets. ${ }^{10}$ In more detail, we calculate adjustment factors for the pension expenditures, the consumption tax (GST) revenue, the corporation tax revenue and other social transfers to match exactly the targeted ratio of each indicator to GDP. ${ }^{11}$ The model overestimates the tax revenues from

TABLE 2: Comparison of Benchmark Solution with Australian Data

\begin{tabular}{|l|l|c|c|}
\hline & Variable & Benchmark model & Australia 2008-20012 \\
\hline \multirow{4}{*}{$\begin{array}{l}\text { Expenditures on GDP } \\
\text { percent of GDP) }\end{array}$} & Private consumption & 55.40 & 54.75 \\
\cline { 2 - 4 } & Investment & 27.06 & 27.60 \\
\cline { 2 - 4 } & Government consumption & 15.66 & 18.10 \\
\cline { 2 - 4 } $\begin{array}{l}\text { Government indicators } \\
\text { (percent of GDP) }\end{array}$ & Trade balance & 1.88 & -0.54 \\
\cline { 2 - 4 } & Age pension expenditure & 2.80 & 2.80 \\
\cline { 2 - 4 } & Other social transfers [b] & 4.20 & 4.20 \\
\cline { 2 - 4 } & Personal income taxes & 12.92 & 11.50 \\
\cline { 2 - 4 } & Corporation taxes & 5.10 & 5.10 \\
\cline { 2 - 4 } & Superannuation taxes & 1.34 & 0.75 \\
\cline { 2 - 4 } & Consumption taxes (GST & 3.50 & 3.50 \\
\hline Calibration target & only) & & 3 \\
\cline { 2 - 4 } & Capital-output ratio & 3 & 0.09 \\
\cline { 2 - 4 } & Investment-capital ratio & 0.09 & 0.195 \\
\cline { 2 - 4 } & Foreign debt-capital ratio & 0.33 & 0.33 \\
\cline { 2 - 4 } & Average hours worked & & \\
\hline
\end{tabular}

Notes : Actual data are taken from ABS (2012b, 2013b, 2013c) and all are averages over 2008-12; [b] These are social security payments excluding payments to the aged (e.g., disability pensions and family benefits).

\footnotetext{
${ }^{10}$ The model also does a good job in matching the net income shares of each income quintile and the Gini coefficient in net income with actual ABS (2013d) data on income distribution. Details of this comparison are available from the author.

${ }^{11}$ The adjustment factor for the pension expenditures is 0.9. This means that the pension payments in Figure 1 are scaled down to account for the use of the maximum pension rate for single pensioners in the model, which is higher than the maximum couple rate of pension (paid to each member of a couple). The statutory consumption tax (GST) rate of 10 percent and the adjustment parameter of 0.65 imply the effective consumption tax of 6.5 percent, accounting for the fact that the GST is being imposed on about 65percent of all consumption goods in Australia. The implied effective corporation tax rate is about 25 percent in the benchmark steady state (i.e., the product of the corporate tax adjustment factor and the statutory rate of 30 percent).
} 


\section{$4 \quad$ Policy simulations and analysis}

We now use the model described and calibrated in the previous sections to simulate hypothetical policy changes in (i) the taper rate to zero, 0.25, 0.75 and one; and (ii) labour earnings exemptions to 100 percent and 0 percent. Each of the hypothetical policy changes is assumed to be implemented in $2012 .^{12}$

The associations between the age pension and the two sources of private income in the benchmark setting and under the selected hypothetical reforms are depicted by Figure 3 . As shown, setting the taper to zero represents a shift to the universal pension (or demogrant) that is paid to all individuals of the age pension age regardless of their assets income and/or labour earnings. In contrast, setting the taper to one represents a strict income test policy that almost halves the maximum private incomes of pensioners to qualify for any pension. As for the two changes in labour earnings exemptions, the figure only shows the association between the age pension and labour earnings because the unchanged taper of 0.5 implies the same age pension schedule for assets income as in the benchmark. In the case of 100 percent labour earnings exemptions, only the assets income is means tested, while the 0 percent earnings exemption policy treats the two sources of private income in the same way as in the benchmark for assets income.

\footnotetext{
${ }^{12}$ Notice that our analysis abstracts from any other policy changes that may affect pension payments and total government spending on the age pension, including the legislated increases in the pension access age from 65 to 67 and in the superannuation guarantee rate from 9 percent to 12 percent of gross wages that are to be phased in gradually in the near future.
} 


\section{FIGURE 3: Association between Age Pension and Private Incomes}
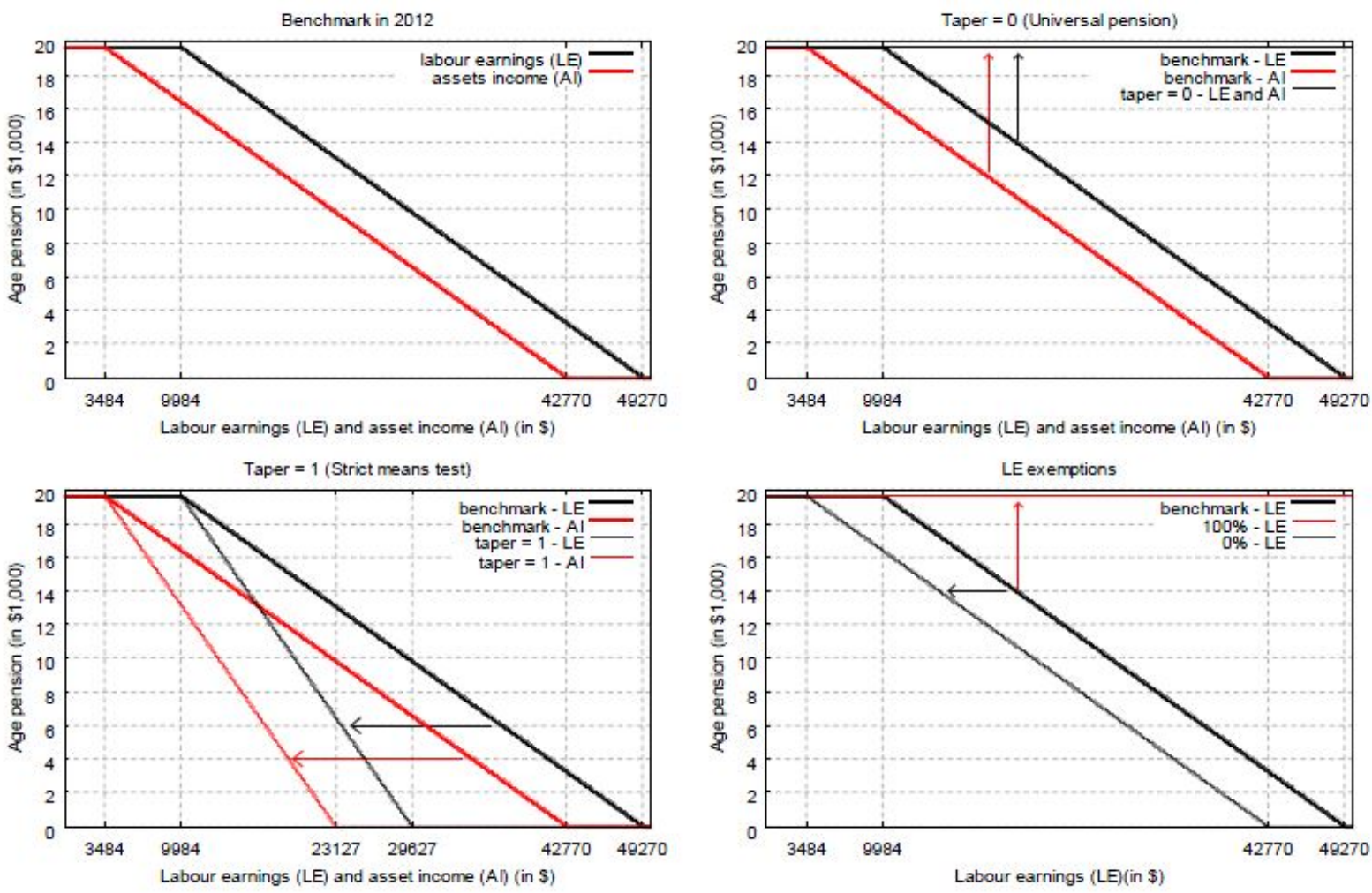

Notes: The benchmark assumes pension settings for single pensioners in 2012, with the taper of 0.5 and labour earnings exemptions of up to $\$ 6,500$ per year. The arrows show the effects of selected policy changes on the association between age pension and private income.

The changes in the age pension schedule reported in Figure 3 are expected to have direct effects upon life-cycle behaviour of households and also indirect or general equilibrium effects due predominantly to the assumed, budget-equilibrating adjustments in the income tax schedule (i.e., proportional changes to average/marginal income tax rates). In this section, we present and discuss disaggregate behavioural effects, as well as the macroeconomic and welfare implications. We start with long run steady state implications and then proceed to short term and transitional implications of the investigated policy changes. 


\subsection{Long run implications}

The long run steady state implications apply if we assume that there has been sufficient time for the economy to adjust completely to the new policy settings. In this case, households of different generations, but of the same income type, face exactly the same economic environments (though at different calendar times) and so behave in exactly the same way. Below we discuss the long run implications separately for the taper rate changes and the change in labour earnings exemptions.

\subsubsection{Taper rate changes}

The long run effects of the taper rate changes on average life-cycle labour supply, consumption and total assets are presented in Figure 4. For ease of exposition, each graph compares the benchmark steady state profile, which is averaged across five income types of households, only with the average profiles obtained from the two extreme changes in the taper to zero (i.e., universal pension) and to one (i.e., strict means test). 
FIGURE 4: The Long Run Steady State Effects of Taper Rate Changes on Average Life Cycle
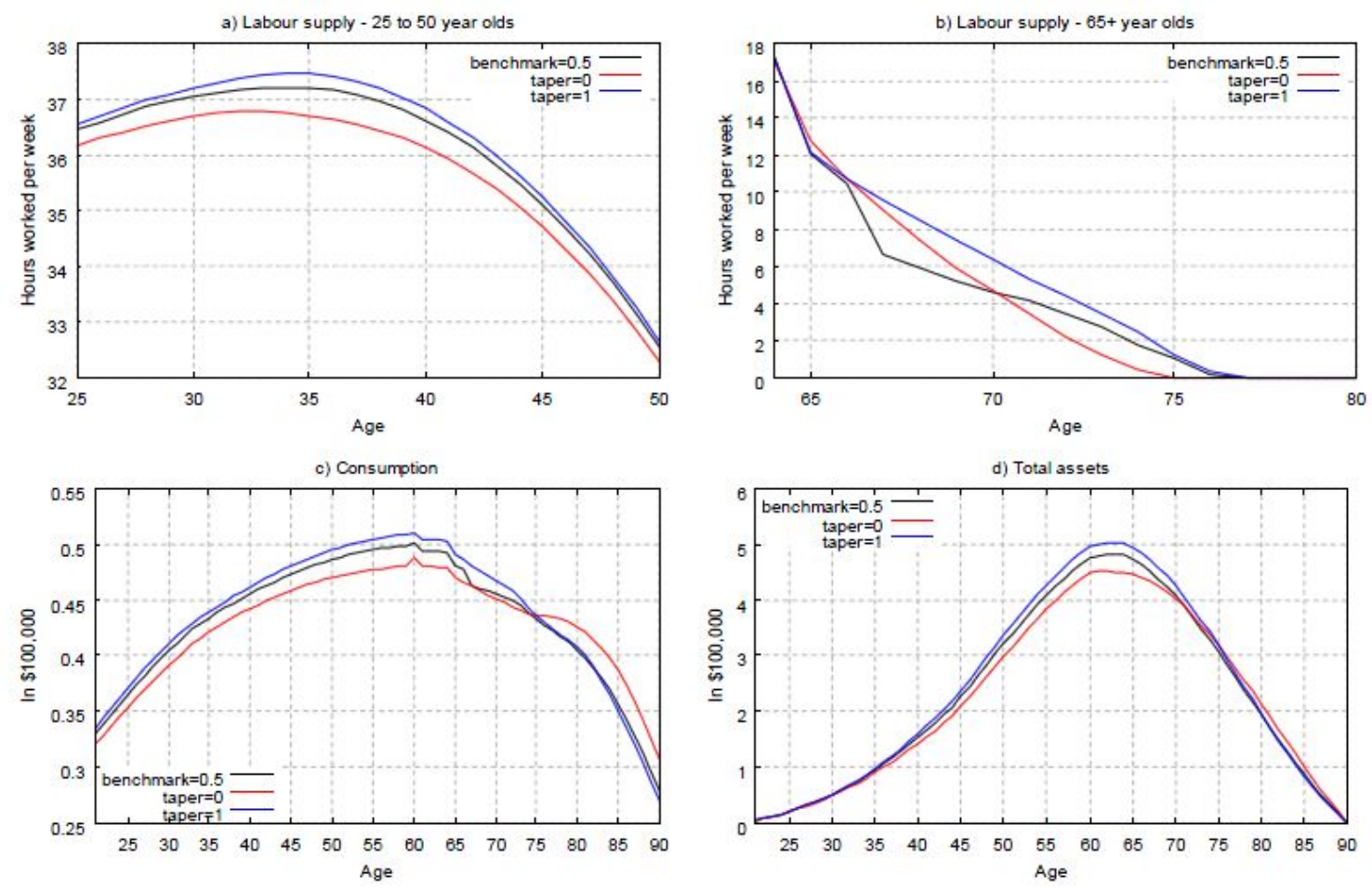

Similarly to Kumru and Piggott (2009) and Fehr and Uhde (2014), the life cycle results indicate that the high taper rate policy leads to less consumption smoothing, but larger assets accumulations for most of the life cycle with steeper assets withdrawals at older ages. Furthermore, as the increased taper lowers average pension payments to elderly households, the associated disincentive to work declines, partly explaining increased labour supply of young and middle age cohorts (Figure 4a). The indirect effect of reduced income tax rates resulting from the strict means test policy also encourages higher average labour supply. The results for the shift to universal pension payments with the taper set to zero show the opposite behavioural effects, compared to those outlined above for the strict means test policy change.

The effects on average labour supply of the high taper rate policy are not only positive for young and middle age cohorts but also for older households aged 65 years and over, as shown in Figure 4b. Table 3 with the disaggregate effects on average labour supply for the 25 to 55 and 65 plus 
year olds shows that under the high taper policy change, many income types aged 65 years and over work longer hours, with average labour supply of 65 plus year olds up by 13.43 percent relative the benchmark. ${ }^{13}$ While the labour supply of older households in the lowest quintile who receive the maximum pension regardless of the taper increases only marginally, the second, third and fourth quintiles at older ages experience significantly higher labour supply. Although the elderly in these quintiles work more to offset reduced pension payments, the labour supply effects differ among the three income groups. Specifically, households in the second quintile work and earn more but the EMTRs on their labour income are not affected by the increased taper because they do not exceed the maximum earnings exemption. The increase in average labour supply of 65 plus year olds in the third quintile is due to an increased retirement age. Note that these households work the same hours at early age pension ages as in the benchmark, in order to avoid high EMTRs on their earnings that they would pay if their labour earnings exceeded the maximum exemption. Finally, households in the fourth quintile no longer qualify for any pension at early age pension ages as a result of the increased taper. They no longer face any labour supply distortions arising from the means testing and, therefore, increase their labour supply and work similar hours as the highest income type of households.

\footnotetext{
${ }^{13}$ Note that the absolute increase in average labour supply of the 65 plus age group is small, with the effects on per capita labour supply discussed below due largely to the changes in working hours of young and middle age cohorts.
} 
TABLE 3: Long Run Effects of Taper Rate Changes on Household Labour Supply

(Percentage Changes in Hours Worked per Week Relative to Benchmark in 2012)

\begin{tabular}{|c|c|c|c|c|c|}
\hline & & \multicolumn{2}{|c|}{ Taper $=0$} & \multicolumn{2}{|c|}{ Taper $=1$} \\
\hline & & $25-50$ & $65+$ & $25-55$ & $65+$ \\
\hline \multirow[t]{6}{*}{ Income quintile } & Lowest & -0.21 & -21.64 & 0.09 & 2.03 \\
\hline & Second & -0.36 & -29.39 & 0.04 & 36.04 \\
\hline & Third & -1.20 & 39.99 & 0.40 & 21.96 \\
\hline & Fourth & -1.93 & 24.77 & 0.93 & 54.65 \\
\hline & Highest & -1.50 & -14.73 & 0.69 & -4.56 \\
\hline & Average & -1.41 & -0.68 & 0.62 & 13.43 \\
\hline
\end{tabular}

Notes: The results relate to average labour supply for 25-55 and 65 plus year olds.

Table 4 reports the long run macroeconomic implications of the examined taper rate changes as percentage changes in the selected per capita variables relative to the benchmark in 2012 . The simulation results of hypothetical increases in the income taper show positive long run effects on most macroeconomic variables, including labour supply, assets and consumption as well as reduced age pension expenditures to the government. ${ }^{14}$ In particular, the taper increased to one generates 0.82 percent increase in labour supply, 4.28 percent increase in domestic assets, 1.63 percent increase in per capita consumption (a measure of living standards) and 17.04 percent reduction in age pension expenditures. The positive effects on per capita labour supply are driven by higher average labour supply of working age households. Conversely, lowering the current taper rate of 0.5 has negative macroeconomic and fiscal implications in the long term. For example, the results for the removal of the means test with the taper set to zero show a significant increase in the age pension expenditures by almost 42 percent from current 2.8 percent of GDP to over 4 percent of GDP, requiring an income tax hike of over 11 percent in the long run.

\footnotetext{
${ }^{14}$ In our small open economy framework, the capital labour ratio as well as the marginal products of capital and labour and the wage rate faced by the firms are all determined by the exogenously given and constant interest rate in the long run. To keep the capital labour ratio unchanged in the long run, the percentage changes in the per capita labour supply have to be matched by the percentage changes in the capital stock. The long run changes in average labour supply also determine the percentage changes in the output per capita because of the constant return to scale property of the production function.
} 
TABLE 4: Macroeconomic Effects of Taper Rate Changes in Long Run (Percentage Changes in Selected Variables Relative to Benchmark in 2012)

\begin{tabular}{|l|c|c|c|c|}
\hline & \multicolumn{4}{|c|}{ Taper rate changes to } \\
\hline Variables & $\mathbf{0}$ & $\mathbf{0 . 2 5}$ & $\mathbf{0 . 7 5}$ & $\mathbf{1}$ \\
\hline Labour supply & -1.38 & -1.06 & 0.40 & 0.82 \\
\hline $\mathbf{- 2 5 - 5 5}$ year olds & -1.41 & -0.59 & 0.34 & 0.62 \\
\hline -65+ year olds & -0.68 & -24.06 & 4.97 & 13.43 \\
\hline Domestic assets & -4.41 & -2.94 & 1.98 & 4.28 \\
\hline Consumption & -2.30 & -1.69 & 0.78 & 1.63 \\
\hline $\begin{array}{l}\text { Age pension } \\
\text { expenditures }\end{array}$ & 41.66 & 18.23 & -9.89 & -17.04 \\
\hline Income tax rates [a] & 11.16 & 6.28 & -3.19 & -6.01 \\
\hline
\end{tabular}

Notes: [a] Adjustments to income taxes assumed to balance government budget.

The results reported above are generally supported by related literature on means testing pensions (e.g., Kumru and Piggott (2009), Tran and Woodland (2014) and Fehr and Uhde, 2014). However, Maattanen and Poutvaara (2007) and Kudrna and Woodland (2011a) found opposite effects of the taper rate changes on aggregate labour supply and consumption. This is due largely to a different choice of the government budget-neutralising policy instrument, with Maattanen and Poutvaara (2007) assumed budget-equilibrating changes in the maximum pension benefit and Kudrna and Woodland (2011a) used budget-equilibrating changes in the consumption tax rate. In addition, Kudrna and Woodland (2011a) assumed only three income types of households, with 30 percent of each generation in the low income class, 60 percent in the middle income class and the remaining 10 percent in the high income class. Therefore, the positive labour supply effects that they found for the means test removal were to some extent a result of increased working hours of middle income households eligible for the pension. Recall that in Table 3, we also show positive labour supply effects of the means test removal (i.e., Taper $=0$ ) for the 65-plus-year-olds in third and fourth quintiles, but these two income types together only account for 40 percent of population in that age group. 


\subsubsection{Changes to labour earnings exemptions}

Here we discuss the long run simulation results for the hypothetical changes in the labour earnings (LE) exemptions from the means testing to 100 percent and to 0 percent. The main objective is to examine the effects of a preferential treatment of labour earnings in the income test of the age pension on labour supply of older Australians.

Figure 5 compares the life-cycle labour supply in the benchmark averaged over five income types of households with the average labour supply profiles obtained from the two policy changes. The differences among the three profiles are significant for older households aged 65 years and over. While the hypothetical removal of the current labour earnings exemptions reduces labour supply at older ages, the 100 percent exemption of labour earnings from the means testing increases average labour supply of older households in comparison with the benchmark labour supply. Under the 100 percent labour earnings exemptions, the increased labour supply of older households is also shown to decline gradually with age. This is because elderly households in the third and fourth quintiles no longer face high EMTRs on their labour income as they did in the benchmark case. Recall that in the benchmark with the current labour earnings exemption, the working hours of the two-income types drop suddenly at early age pension ages (see the life-cycle labour supply in Figure 1 for the two quintiles). 


\section{FIGURE 5: Long Run Labour Supply Effects of Changes in LE Exemptions}

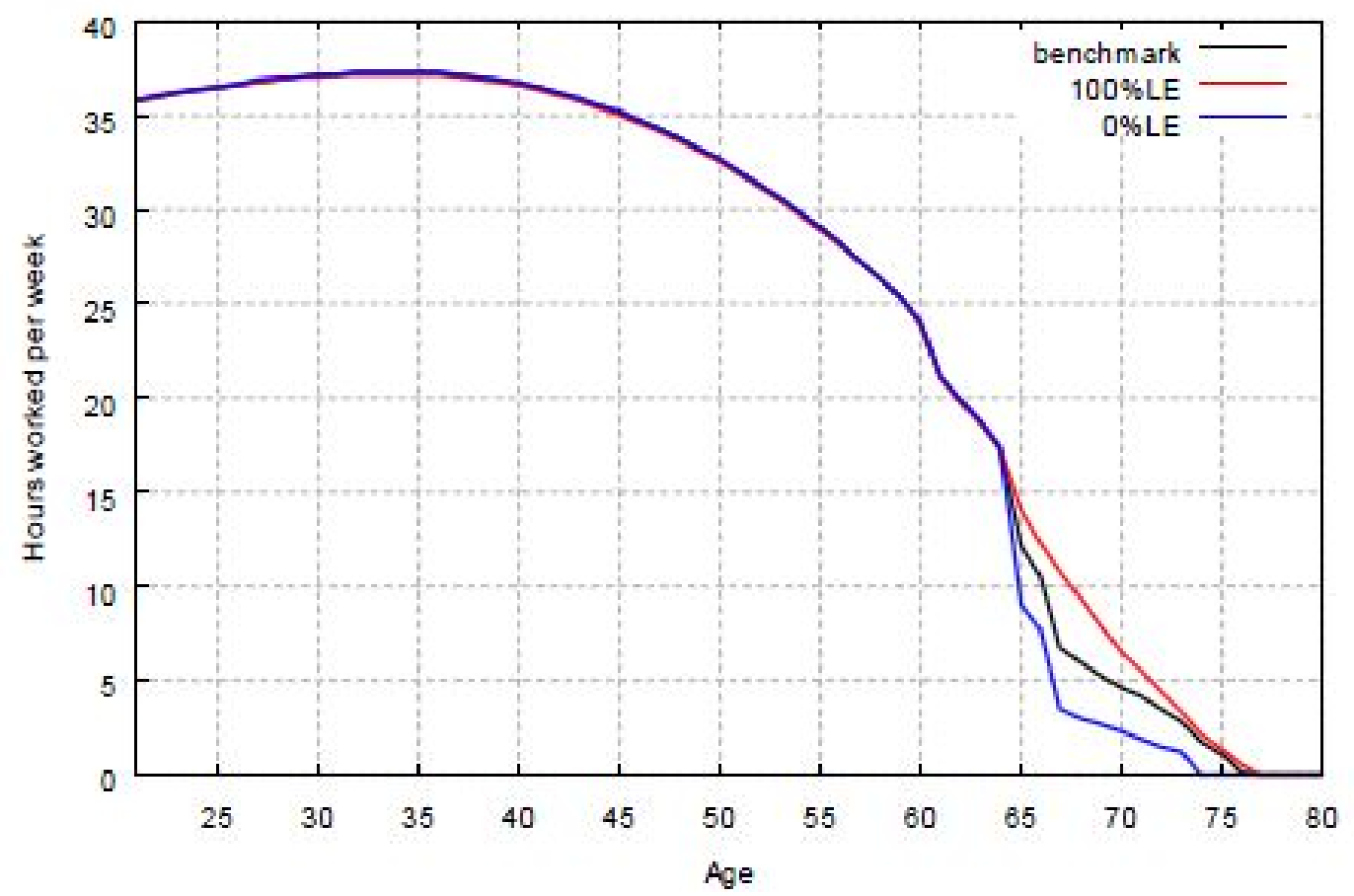

Notes: The results relate to average labour supply over five income types of households.

The long run macroeconomic effects of the two policy changes in labour earnings exemptions are provided in Table 5. Compared to the examined taper rate changes, the changes in labour earnings exemptions have much smaller aggregate effects, which are due to the assumed low and declining productivity at older ages, and relatively smaller numbers of people affected. Importantly, labour earnings exemptions from the means testing have significant and positive effects on average labour supply of older Australians. The results for the 100 percent labour earnings exemptions show a 24.64 percent long run increase in average labour supply of households aged 65 years and older, which is almost a double of the long run increase in labour supply of the elderly resulted from the strict means test policy with the taper increased to one. 
TABLE 5: Macroeconomic Effects of Labour Earnings Exemptions in Long Run (Percentage Changes in Selected Variables Relative to Benchmark in 2012)

\begin{tabular}{|l|l|l|}
\hline & \multicolumn{2}{|l|}{ Changes in labour earnings examptions to } \\
\hline Variables & $\mathbf{1 0 0 \%}$ & $\mathbf{0 \%}$ \\
\hline Labour supply & 0.30 & -0.48 \\
\hline $\mathbf{- 2 5 - 5 5}$ year olds & -0.34 & 0.12 \\
\hline$-65+$ year olds & 24.64 & -24.47 \\
\hline Domestic assets & -2.94 & 1.33 \\
\hline Consumption & -0.07 & -0.38 \\
\hline Age pension expenditures & 2.64 & -0.22 \\
\hline Income tax rates [a] & 0.88 & 0.35 \\
\hline
\end{tabular}

Notes: [a] Adjustments to income taxes assumed to balance government budget.

Table 5 also shows increased age pension expenditures as a result of the 100 percent labour earnings exemptions, which calls for higher income tax rates assumed to maintain a balanced government budget. Higher income tax rates together with increased pension payments lead to smaller assets accumulations. As mentioned, the magnitude of these aggregate effects is much smaller relative to the macroeconomic implications of the taper rate changes (see Table 4 for comparison).

\subsection{Transitional implications}

The long run simulation results established that only the changes in the taper rate had significant effects on the Australian economy. In this subsection, we therefore focus on transitional implications of the taper rate changes for the key macroeconomic variables and welfare of different households.

\subsubsection{Macroeconomic Effects}

The macroeconomic effects of the taper rate changes on labour supply, domestic assets and consumption (all measured in per capita terms) upon the impact in 2012 and over the transition 
are depicted by Figure 6 . These effects are presented as percentage changes in the selected variables relative to their benchmark steady state values, with the results for year 2070 approximating the long run effects presented above.

\section{FIGURE 6: Macroeconomic Effects of Taper Rate Changes over Transition}
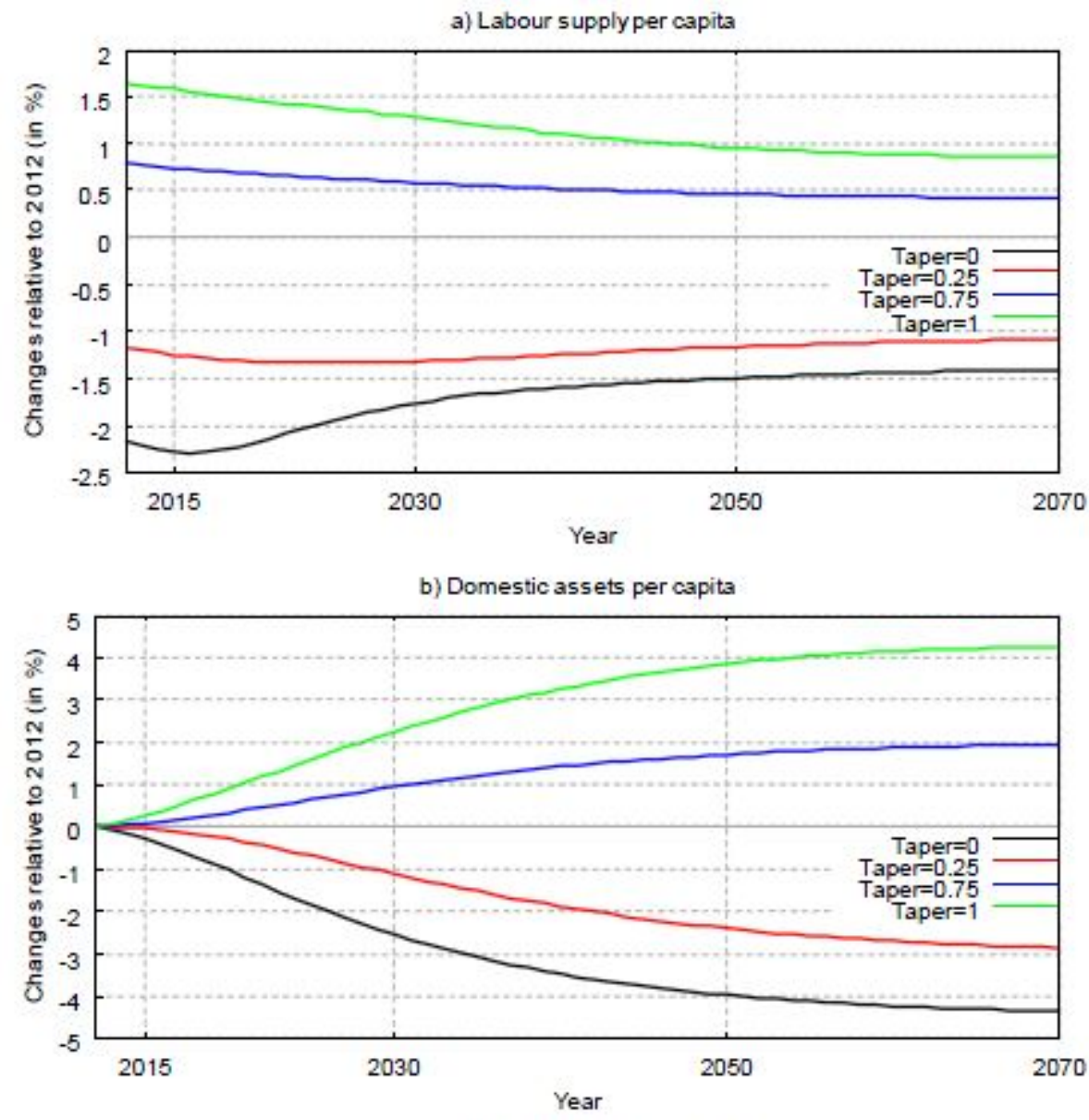

c) Consumption per capita

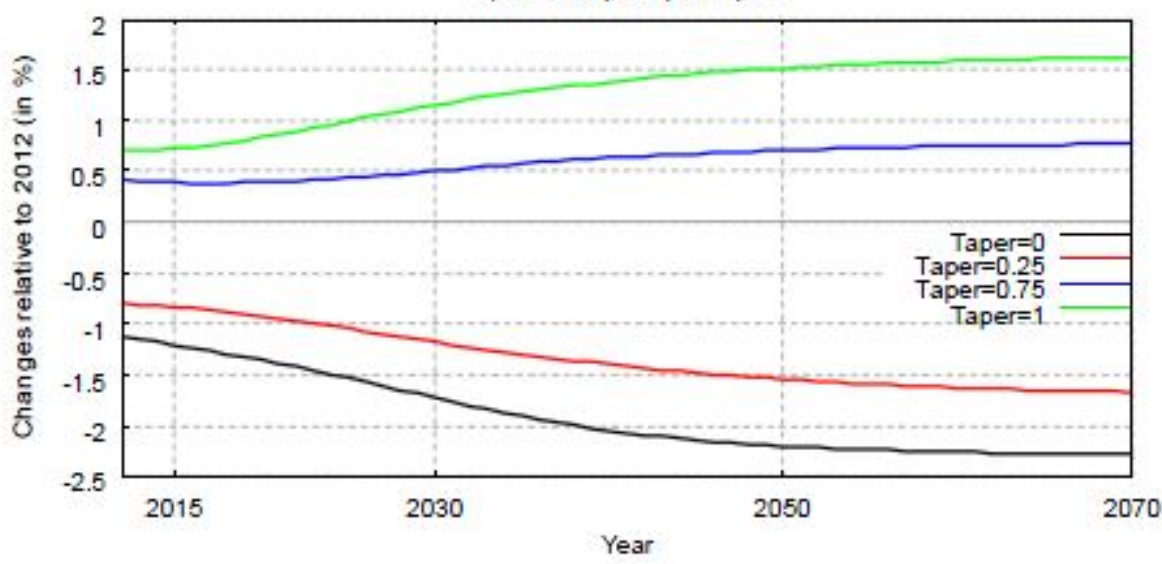


Several observations can be drawn from Figure 6. First, the examined increases in the taper from the benchmark rate of 0.5 (combined with the budget-equilibrating reductions in income tax rates) generate higher per capita labour supply, assets and consumptions during the transition. Second, the short run effects on per capital labour supply are larger than the long run implications as current middle age and older cohorts work more to offset large cuts in their pensions. The transitional decreases in per capita labour supply relative to the impact effect are due to greater assets accumulations by future born generations, which have an income effect on their labour supply. Nevertheless, the strict means test policy with the taper increased to one still generate a more than 0.8 percent long-run increase in per capita labour supply. Third, the effects of the two examined reductions in the taper rate are almost symmetrically opposite to the higher taper rate changes. For example, the shift to universal pension payments with the taper set to zero is shown to reduce per capita labour supply more in the short run than in the long run. Older households significantly reduce their working hours because of receiving higher (full) pensions, while future born generations accumulate smaller assets due to increased income tax rates. As a result, per capita labour supply improves but per capita consumption worsens in the subsequent years of the transition.

The transitional effects of the taper rate changes on the age pension expenditures and the budgetequilibrating income tax rates (not presented) are similar to the long run effects (see Table 4). Specifically, the zero taper policy change increases the age pension expenditures by 41.66 percent upon the impact and in the long run as we assume stationary demographics. The examined increases in the income taper reduce the pension expenditures significantly in the short run, allowing for an immediate income tax cut. Over time, the pension expenditures (and thus 
income tax rates) decline further because future generations accumulate larger assets that generate higher assets income assessed under the income test of the age pension.

\subsubsection{Welfare effects}

The welfare effects are assessed on the basis of standard equivalent variations. Following Nishiyama and Smetters (2007), we calculate the change in initial wealth/assets for each generation needed in the benchmark to produce remaining lifetime utility obtained under the policy change. The average welfare effects of the examined policy change (i.e., average welfare across the five income groups) as a function of cohort's age at the time of the policy change are plotted in Figure 7. Recall that each hypothetical change is assumed to be adopted in 2012, with the cohort aged 21 years being the youngest alive at the time of the policy implementation.

\section{FIGURE 7: Average Welfare Effects of Means Test Changes (Equivalent Variations of Wealth Transfers at Time of Policy Change)}

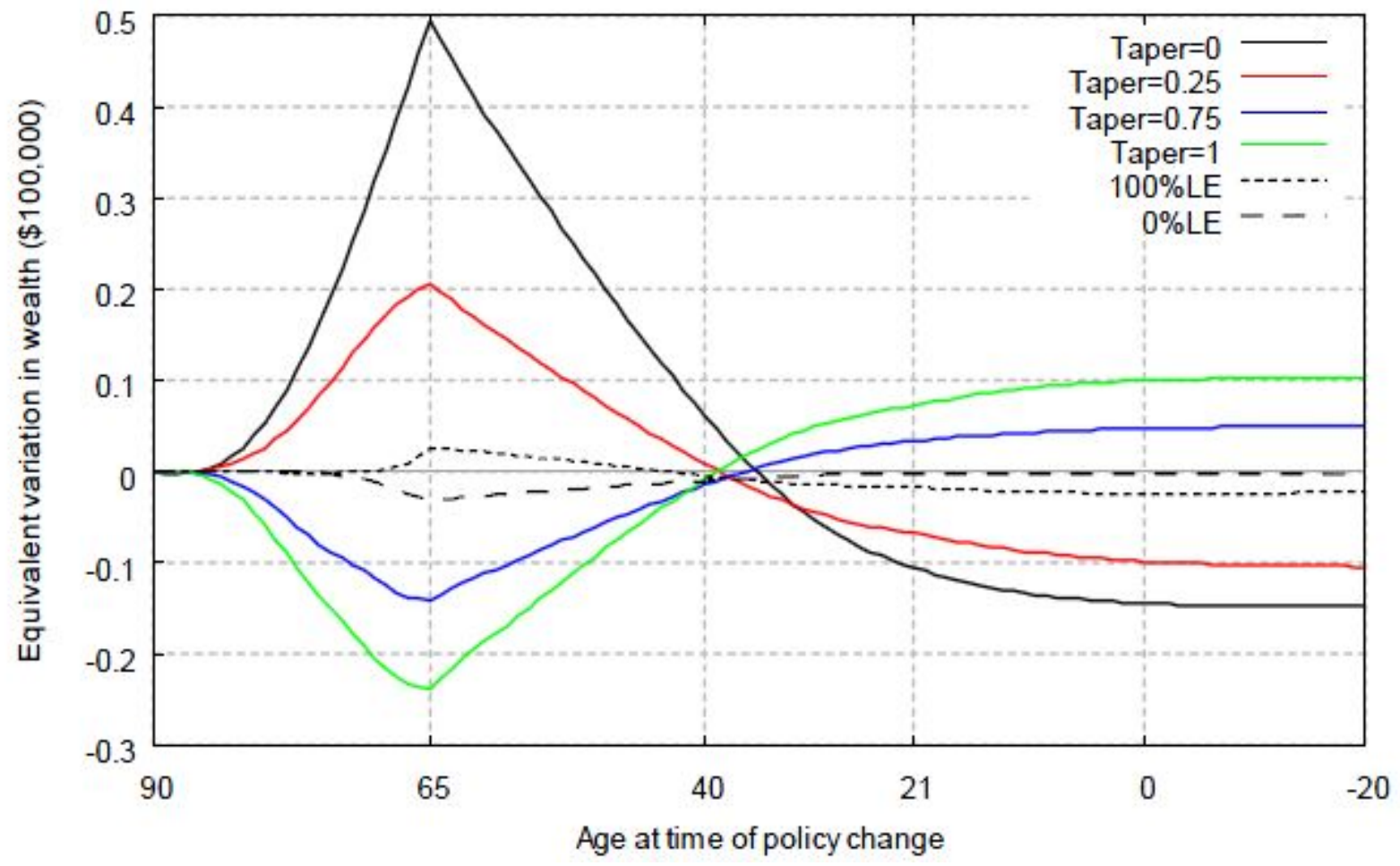

Notes: The presented welfare results for each cohort are averaged over five income groups. 
Similarly to the long run macroeconomic effects, Figure 7 indicates that (i) the welfare effects are almost symmetrically opposite for the two increases and the two reductions in the pension taper rate, and (ii) the welfare effects of the changes in the labour earnings ex- emptions are much smaller compared to those obtained from the taper rate changes. Under the increased taper rate changes, the elderly population and households approaching retirement in 2012 experience larger welfare losses due to pension cuts, while young and future generations, on average, gain in welfare as they benefit from lower income tax rates and in- creased savings. Conversely, the investigated reductions in the taper rate have significantly positive effects on the welfare of currently old and middle-age households (who all receive full pension) but negative effects on the welfare of future generations. For instance, consider the generation aged 65 years in 2012. This generation would gain almost $\$ 50,000$ in initial resources under the zero taper policy, whereas the same cohort loses, on average, almost $\$ 24,000$ in the case of the taper increased to one. In the long run, however, the average welfare is shown to increase by over $\$ 10,000$ for the increased taper policy and to decline by about $\$ 15,000$ as a result of the zero taper policy. One should also note that current young and future generations who gain from the increased taper are larger in size compared to currently old generations.

The average welfare effects of the taper rate changes are further decomposed in Table 6, which shows both the intergenerational implications for the selected cohorts and the intragenerational implications for each income quintile. The effects are presented as equivalent variations of onetime wealth transfers and are shown to be greater for higher income quintiles as they hold much larger lifetime wealth compared to lower income types. In fact, the welfare of households in the lowest quintile is affected only indirectly through the budget- equilibrating changes in income 
tax rates as these households eligible for the pension receive the maximum payment regardless of the taper. The welfare implications for higher income quintiles are also affected by direct effects of the changes in their current or future pension payments.

TABLE 6: Distributional Welfare Effects of Taper Rate Changes (Equivalent Variations of One-Time Wealth Transfers at Time of Policy Change)

\begin{tabular}{|c|c|c|c|c|c|c|}
\hline \multirow[b]{2}{*}{ Policy change } & \multirow[b]{2}{*}{ Age in 2012} & \multicolumn{5}{|c|}{ Household income type } \\
\hline & & Lowest & Second & Third & Fourth & Highest \\
\hline \multirow[t]{5}{*}{ Taper $=0$} & 80 & -0.01 & -0.01 & 0.02 & 0.07 & 0.19 \\
\hline & 65 & -0.02 & 0.12 & 0.41 & 0.78 & 1.19 \\
\hline & 40 & -0.02 & 0.05 & 0.12 & 0.16 & -0.01 \\
\hline & 21 & -0.01 & 0.01 & -0.01 & -0.08 & -0.42 \\
\hline & -80 & -0.02 & -0.01 & -0.05 & -0.14 & -0.52 \\
\hline \multirow[t]{5}{*}{ Taper $=0.25$} & 80 & 0.00 & 0.00 & 0.01 & 0.03 & 0.10 \\
\hline & 65 & -0.01 & 0.06 & 0.20 & 0.38 & 0.41 \\
\hline & 40 & -0.01 & 0.03 & 0.06 & 0.07 & -0.11 \\
\hline & 21 & -0.01 & 0.00 & -0.01 & -0.05 & -0.27 \\
\hline & -80 & -0.01 & -0.01 & -0.03 & -0.09 & -0.37 \\
\hline \multirow[t]{5}{*}{ Taper $=0.75$} & 80 & 0.00 & 0.00 & -0.01 & -0.04 & -0.10 \\
\hline & 65 & 0.01 & -0.06 & -0.20 & -0.28 & -0.17 \\
\hline & 40 & 0.00 & -0.03 & -0.08 & -0.08 & 0.12 \\
\hline & 21 & 0.00 & -0.01 & -0.02 & 0.00 & 0.19 \\
\hline & -80 & 0.01 & -0.01 & 0.01 & 0.02 & 0.23 \\
\hline \multirow[t]{5}{*}{ Taper $=1$} & 80 & 0.00 & 0.00 & -0.02 & -0.07 & -0.21 \\
\hline & 65 & 0.01 & -0.11 & -0.38 & -0.48 & -0.23 \\
\hline & 40 & 0.01 & -0.06 & -0.17 & -0.09 & 0.27 \\
\hline & 21 & 0.01 & -0.02 & -0.05 & 0.05 & 0.37 \\
\hline & -80 & 0.01 & -0.01 & -0.03 & 0.09 & 0.45 \\
\hline
\end{tabular}

Notes: Initial wealth transfers presented in units of $\$ 100,000$.

Table 6 shows that the examined increases (reductions) in the taper result in welfare losses (gains) to currently older generations due to lower (higher) pension payments. For example, in the case of the zero taper, the welfare gain for the highest quintile aged 65 years in 2012 is $\$ 119,000$ in initial wealth. In other words, the initial wealth of this high income household would need to increase by that amount to generate the level of remaining lifetime utility in the benchmark with the taper of 0.5 as under this policy change with the zero taper. In contrast, 
future generations of households in the highest quintile experience large welfare losses ( $\$ 52,000$ in initial wealth) under the zero taper policy that increases disincentives to work and save and requires higher income tax rates. Note that lower income tax rates resulting from the increased taper are particularly important for higher income households to attain welfare gains in the long run.

\section{$5 \quad$ Sensitivity analysis}

In this section, we examine the sensitivity of long run macroeconomic and welfare results obtained from the taper rate changes to several modifications of the model. The first modification assumes an alternative policy instrument to balance the government budget, while the second alteration allows for the domestic interest rate to be endogenous. In the third modification, we examine the long run effects of the taper rate changes in an ageing environment.

Table 7 reports the percentage point deviations between the taper rate changes obtained under each alternative model assumption and those obtained using the baseline model re- ported above for selected macroeconomic variables and welfare measures, respectively. 
TABLE 7: Sensitivity of Long Run Effects of Taper Changes to Alternative Assumptions (Percentage Point Deviations in Selected Variables from Baseline Results in Long Run)

\begin{tabular}{|c|c|c|c|c|c|}
\hline \multirow[b]{2}{*}{$\begin{array}{l}\text { Alternative } \\
\text { assumptions }\end{array}$} & \multirow[b]{2}{*}{ Variables } & \multicolumn{4}{|c|}{ Taper rate changes to } \\
\hline & & 0 & 0.25 & 0.75 & 1 \\
\hline \multirow{7}{*}{$\begin{array}{l}\text { (i) } \\
\text { Consumption } \\
\text { tax balancing } \\
\text { government } \\
\text { budget }\end{array}$} & Labour supply & 1.03 & 0.41 & -0.18 & -0.30 \\
\hline & $\begin{array}{l}\text { Domestic } \\
\text { assets }\end{array}$ & 4.03 & 3.60 & -2.32 & -3.92 \\
\hline & Consumption & 1.82 & 1.01 & -0.57 & -0.95 \\
\hline & Tax rate [a] & 28.79 & 15.31 & -7.69 & -15.63 \\
\hline & $\begin{array}{l}\text { Welfare - } \\
\text { lowest type }\end{array}$ & -0.39 & -0.20 & 0.09 & 0.20 \\
\hline & $\begin{array}{l}\text { Welfare - } \\
\text { highest type }\end{array}$ & 0.80 & 0.48 & -0.26 & -0.46 \\
\hline & $\begin{array}{l}\text { Welfare - } \\
\text { average }\end{array}$ & -0.03 & 0.00 & -0.01 & 0.02 \\
\hline \multirow{8}{*}{$\begin{array}{l}\text { (ii) } \\
\text { Endogenous } \\
\text { domestic } \\
\text { interest rate }\end{array}$} & Labour supply & -0.27 & -0.14 & 0.08 & 0.22 \\
\hline & $\begin{array}{l}\text { Domestic } \\
\text { assets }\end{array}$ & 0.65 & 0.23 & -0.54 & -0.83 \\
\hline & Interest rate & 1.27 & 0.90 & -0.56 & -1.39 \\
\hline & Consumption & -0.39 & -0.25 & 0.07 & 0.30 \\
\hline & Tax rate $[\mathrm{b}]$ & 0.80 & 0.54 & -0.14 & -0.49 \\
\hline & $\begin{array}{l}\text { Welfare - } \\
\text { lowest type }\end{array}$ & -0.07 & -0.05 & 0.03 & 0.08 \\
\hline & $\begin{array}{l}\text { Welfare - } \\
\text { highest type }\end{array}$ & -0.15 & -0.10 & 0.04 & 0.11 \\
\hline & $\begin{array}{l}\text { Welfare - } \\
\text { average }\end{array}$ & -0.08 & -0.06 & 0.03 & 0.09 \\
\hline \multirow{7}{*}{$\begin{array}{l}\text { (iii) Population } \\
\text { ageing }\end{array}$} & Labour supply & -1.83 & -1.14 & 0.52 & 1.09 \\
\hline & $\begin{array}{l}\text { Domestic } \\
\text { assets }\end{array}$ & -0.42 & -0.45 & 1.70 & 5.69 \\
\hline & Consumption & -2.51 & -1.61 & 1.16 & 2.97 \\
\hline & Tax rate [b] & 4.58 & 2.80 & -2.34 & -5.47 \\
\hline & $\begin{array}{l}\text { Welfare - } \\
\text { lowest type }\end{array}$ & -0.29 & -0.18 & 0.14 & 0.30 \\
\hline & $\begin{array}{l}\text { Welfare - } \\
\text { highest type }\end{array}$ & -1.32 & -0.74 & 0.51 & 1.19 \\
\hline & $\begin{array}{l}\text { Welfare - } \\
\text { average }\end{array}$ & -0.55 & -0.32 & 0.23 & 0.51 \\
\hline
\end{tabular}

Notes: Welfare is measured by standard equivalent variations; [a] Budget-equilibrating consumption tax changes; [b] Budget-equilibrating income tax changes.

\subsection{Consumption tax balancing budget}

We have so far assumed proportional changes in the income tax schedule to balance the government budget. In this variation of the model, the income tax schedule is assumed to be unchanged and the government budget is balanced by adjustments made to the consumption tax 
rate, as assumed by Kudrna and Woodland (2011a) and Fehr and Uhde (2014). The motivation for this robustness check is that the two tax instruments have potentially different incentive effects upon households and, hence, upon the economy.

The two examined increases (reductions) in the pension taper rate allows for (requires) a lower (higher) consumption tax rate, as shown in Table 7. The percentage changes in the consumption tax rate are significantly greater than in the income tax rates (see Table 4 for comparison) because of much smaller revenues generated by consumption taxes. More importantly, given that taxing consumption is less distortive for household behaviour than income taxation, tightening the taper with a reduced consumption tax rate has relatively negative long run effects on the selected macroeconomic variables. For instance, using the consumption tax rate rather than the income taxation to balance the government budget, the policy change of the taper increased to one reduces the long run increases in per capita labour supply and domestic assets by 0.3 and 3.92 percentage points, respectively.

The two tax policy instruments have also different effects on welfare of low and high income households, which in Table 7 are depicted by the effects on the lowest and highest income quintiles. In particular, increasing the taper with a reduced consumption tax rate improves (worsens) welfare of the lowest (highest) income quintile, whereas the opposite is shown for the examined taper reductions. Note that consumption taxes are regressive and income taxes are progressive. Hence, a reduction in the consumption tax rate has stronger positive welfare effects on low income households than on high income households who benefit more from an income tax cut with reduced marginal income tax rates. 


\subsection{Endogenous interest rate}

We now relax the small open economy assumption and assume imperfect capital mobility with an endogenous domestic interest rate that depends upon the level of foreign debt. Specifically, the domestic interest rate is given by $r_{t}=\bar{r}+\gamma\left(F D_{t} / Y_{t}-F D_{2012} / Y_{2012}\right)$, where $\bar{r}$ is the exogenous world interest rate and $F D_{t} / Y_{t}$ is the ratio of net foreign debt to output. The parameter $\gamma$ gives responsiveness to the changes in $F D_{t} / Y_{t}$ and is set to 0.02 , as in Guest (2006). Under this specification, the domestic interest rate will fall if $F D_{t} / Y_{t}$ declines and (similarly to a closed economy) the capital labour ratio and the wage rate will no longer be constant in the long run.

As shown in Table 7, increasing the taper rate leads to a lower domestic interest rate. The interest rate declines because of larger domestic assets (also depicted by the baseline simulations with a constant interest rate) being partly invested abroad, thus reducing foreign debt. On the one hand, the reduced rate of return has somewhat negative effects on per capita assets in the long run, as reported in Table 7 for the two increases in the pension taper rate. On the other hand, the positive effects on per capita labour supply and consumption (and on the economy through increases in GDP per capita) are higher than those obtained previously with the fixed interest rate. These effects are due to increased wages (not displayed). ${ }^{15}$ The long run welfare gains from the increased taper reforms are also higher for the two selected quintiles and average welfare, due primarily to relatively higher wages and lower income tax rates. On the basis of these welfare results (and the implications presented above for key macro variables) we conclude that an

\footnotetext{
${ }^{15}$ The lower interest rate drives up investment, leading to a larger capital stock. Consequently, the capital labour ratio increases, which has positive effects upon wages. Note that similar effects would occur in a closed economy.
} 
endogenous interest rate setup such as the one applied in this section provides an additional support for the means testing of pension pensions.

\subsection{Population ageing}

Our sensitivity analysis of the baseline results to population ageing makes use of the medium population projections by Productivity Commission (2013). In particular, we use their agespecific survival rates in 2060 and calculate the annual rate of population growth to generate an

old-age dependency ratio of 0.42 taken from their projections for 2060 . The long run steady state effects of the taper rate changes in this ageing environment (with improved survival rates and lower population growth) are then compared with the baseline effects in Section 4.

The results in Table 7 indicate that both the reported macroeconomic aggregates and welfare increase more in this ageing environment than in the baseline model with existing demographics. For instance, domestic assets per capita and average welfare across the income quintiles are 5.69 and 0.51 percentage points higher, respectively, in the long run.

The logic behind the results in Table 7 for the changes in the pension taper rate in an ageing economy is as follows. Population ageing with an increasing proportion of the elderly in the population results in higher pension expenditures, which need to be financed with higher taxes. Strengthening the means testing of the age pension limits the increases in pension expenditures and income taxes. This is partly due to the increased taper rate but also to the means testing of larger assets and assets income. Notice that households respond to increased longevity and improved survival probabilities by accumulating larger assets, which generate higher assets income assessed under the means test. Therefore, the percentage decline in the required tax rates in an ageing environment is greater than that reported in the previous section with the current 
demographic structure. This explains positive effects of the means testing on the economy and welfare in an ageing economy when compared with the effects in a non-ageing environment. ${ }^{16}$

\section{Concluding remarks}

In this paper, we have examined the implications of the means testing of Australia's age pension for life-cycle labour supply and assets, macroeconomic aggregates and household welfare. We base our analysis on a computable OLG model with the capacity to investigate policy changes in the taper rate at which the pension is withdrawn and in labour earnings exemptions from the means testing.

On the basis of our simulations of strengthening the pension means test via raising the taper, we show higher per capita labour supply, assets, consumption and long-term welfare gains. Interestingly, tightening the taper increases labour supply of not only young and future generations, but also generations at early age pension ages. These positive effects of the means testing are due partly to reduced public pension payments (and associated disincentives to work and save) and partly to lower income taxes assumed to balance the government budget with reduced pension expenditures. Similarly to Fehr and Uhde (2014), we find significant welfare losses attained by many currently older generations who have their pension payments reduced as a result of increasing the taper. Note that these short run welfare losses could be minimised by implementing such policy change gradually over the next few decades to allow households to have enough time to adjust their behaviour.

\footnotetext{
${ }^{16}$ In contrast, the policies that relax the means testing require significantly higher income tax rates, which distort households' labour supply and savings, causing larger percentage declines in per capita labour supply and assets than in a non-ageing environment.
} 
We also show that while relaxing the means test for income earned from employment has little aggregate impact (including implications for government pension expenditures), the policy change has important and largely positive effects on labour supply at older ages.

Our findings have important policy implications not only for Australia but also for other ageing economies facing large future pension liabilities. Strengthening the means test generates significant reductions in overall government spending on the pension. Therefore, the policy could be used as an alternative (with potentially more equitable distributional implications) to increasing the pension access age that was recently proposed by the Australian government. Furthermore, our robustness checks indicate that an endogenous interest rate framework (such as imperfect capital mobility or closed economy) and an ageing environment in particular further strengthen the case for the means testing of public pensions. Such pension reforms of tightening the taper combined with exemptions of employment income from pension means tests have recently been recommended for advanced economies by the International Monetary Fund (2014). 


\section{References}

[1] Auerbach, A., and L. Kotlikoff. Dynamic Fiscal Policy. Cambridge: Cambridge University Press, 1987.

[2] Australian Bureau of Statistics (ABS). "Government Benefits, Taxes and Household Income." Cat. No. 6537.0, Australian Government Publishing Service, 2012a.

[3] ABS. "Australian System of National Accounts 2011-12." Cat. No. 5204.0, Australian Government Publishing Service, 2012b.

[4] ABS. "Life Tables - Australia 2010-2012." Cat. No. 3302.0.55.001, Australian Government Publishing Service, 2013a.

[5] ABS. "Government Finance Statistics 2011-12." Cat. No. 5512.0, Australian Government Publishing Service, 2013b.

[6] ABS. "Taxation Revenues 2011-12." Cat. No. 5506.0, Australian Government Publishing Service, 2013c.

[7] ABS. "Household Income and Income Distribution 2011-12." Cat. No. 6523.0, Australian Government Publishing Service, 2013d.

[8] Australian Treasury. "Australia to 2050: Future Challenges." Commonwealth of Australia, 2010.

[9] Baker, M., and D. Benjamin. "How Do Retirement Tests Effect the Labour Supply of Older Men?" Journal of Public Economics, 72, 1999, 27-51. 
[10] Cho, S., and R. Sane. "Means-Tested Age Pensions and Homeownership: Is There a Link?" Macroeconomic Dynamics, 17(6), 2013, 1281-1310.

[11] Disney, R., and S. Smith. "The Labour Supply Effect of the Abolition of the Earnings Rule for Older Workers in the United Kingdom." Economic Journal, 112, 2002, C136- C152.

[12] Fehr, H. "Pension Reform During the Demographic Transition." Scandinavian Journal of Economics, 102(3), 2000, 419-443.

[13] Fehr, H., and J. Uhde. "On the Optimal Design of Pension Systems." Empirica, 40, 2013, 457-482.

[14] Fehr, H., and J. Uhde. "Means-Testing and Economic Efficiency in Pension Design." Economic Modelling, 44, 2014, 57-67.

[15] Friedberg, L. "The Labour Supply Effects of the Social Security Earnings Test." Review of Economics and Statistics, 82, 2000, 48-63.

[16] Gokhale, J., L. Kotlikoff, J. Sefton, and M. Weale. "Simulating the Transmission of Wealth Inequality via Bequests." Journal of Public Economics, 79, 2001, 93-128.

[17] Guest, R. "Population Aging, Capital Mobility and Optimal Saving." Journal of Policy Modeling, 28, 2006, 89-102.

[18] International Monetary Fund. "Fiscal Policy and Income Inequality." IMF Policy Paper, 2014.

[19] Kitao, S. "Sustainable Social Security: Four Options." Review of Economic Dynamics, 17(4), 2014, 756-779. 
[20] Kudrna, G., and A. Woodland. "An Intertemporal General Equilibrium Analysis of the Australian Age Pension Means Test." Journal of Macroeconomics, 33, 2011a, 61-79.

[21] Kudrna, G., and A. Woodland. "Implications of the 2009 Age Pension Reform in Australia: A Dynamic General Equilibrium Analysis." Economic Record, 87, 2011b, 183- 201.

[22] Kumru, C., and J. Piggott. "Should Public Retirement Provision Be Means-Tested?" AIPAR Working Paper No. 01, 2009.

[23] Kumru, C., and J. Piggott. "Optimal Capital Income Taxation with Means-Tested Benefits?" CEPAR Working Paper No. 13, 2012.

[24] Maattonen, N., and P. Poutvaara. "Should Old-Age Benefits Be Earnings-Tested?" IZA Discussion Paper No. 2616, 2007.

[25] Nishiyama, S., and K. Smetters. "Does Social Security Privatization Produce Efficiency Gains?" Quarterly Journal of Economics, 122, 2007, 1677-1719.

[26] OECD (Organisation for Economic Cooperation and Development). "Pensions at a Glance." OECD, Paris, 2013. 